PSYCHOLOGIA ROZWOJOWA, $2019 *$ tom 24 , nr 4, s. 83-95

doi:10.4467/20843879PR.19.024.11730

www.ejournals.eu/Psychologia-Rozwojowa

MARTA KARBOWA-PŁOWENS (D) orcid.org/0000-0003-1692-6564

Instytut Psychologii, Uniwersytet im. Adama Mickiewicza, Poznań

Faculty of Psychology and Cognitive science, Adam Mickiewicz University, Poznan mkarbowa@amu.edu.pl

\title{
Rozwój i charakterystyka więzi przywiązaniowej w relacji romantycznej ${ }^{1}$
}

\section{The Development and Characteristic of the Attachment Bond in Romantic Relationships}

\begin{abstract}
The article presents the development of the attachment bond in romantic relationships and its main characteristics by comparison to child-caregiver attachment. The description of the developmental process begins with infant attachment styles, traces it through the adolescence period, finally accounting for how the attachment bond develops in adults engaged in romantic relationships. Similarities and differences between child and adult attachment styles are pointed out.
\end{abstract}

Keywords: attachment in love relationships, romantic attachment, development of attachment in adulthood

Słowa kluczowe: przywiązanie w związku miłosnym, przywiązanie romantyczne, rozwój przywiązania w dorosłości

\section{WSTĘP}

Przywiązanie do drugiej osoby to zjawisko, które trwa „od kołyski aż po grób” (Bowlby, 1969/2007). Stwierdzenie to zawiera koronną tezę Bowlby’ego, w myśl której przywiązanie jest fenomenem stanowiącym nieodłączny element ludzkiego życia.

Inge Bretherton (1995) podaje, że we wczesnych latach 70. XX wieku po raz pierwszy poddano refleksji kwestię przywiązania w relacji dwojga dorosłych osób. Kontekstem tych rozważań były prowadzone w tamtym czasie badania nad zjawiskiem żałoby dorosłych po stracie partnera/partnerki (Bowlby, Parkes, 1970; Parkes, 1972) oraz małżeńskiej separacji i samotności osób dorosłych (Weiss, 1973; 1977). Jednak dopiero w połowie lat 80 . rozpoczęto systematyczne badania w tym zakresie (Weiss, 1991). Za przełomową pracę należy uznać opublikowany w 1987 roku w „Journal of Personality and Social Psychology" artykut Cindy Hazan i Philipa Shavera (1987) pod tytułem Miłość romantyczna skonceptualizowana jako proces przywiazaniowy ${ }^{2}$.W pierwszym zdaniu abstraktu tej publikacji czytamy(s. 1, tłum. własne):

W artykule analizuje się możliwość uznania miłości romantycznej za proces przywiązaniowy - proces biospołeczny, w wyniku którego powstają emocjonalne więzi między dorosłymi kochankami, analogicznie do emocjonalnej więzi, jaka tworzy się między niemowlętami a ich rodzicami.

Warto podkreślić, że miłosną relację dwojga dorosłych osób porównuje się tutaj z przywiązaniem, przeprowadzając $\mathrm{w}$ dodatku analogię z przywiązaniem dziecięcym³ ${ }^{3}$. Autorzy wskazuja, 
że ten sam system behawioralny, który jest odpowiedzialny za konsolidowanie się przywiązania dziecięcego, uczestniczy w budowaniu więzi pomiędzy dorosłymi.

Teza autorów o paraleli przywiązania dziecięcego i przywiązania romantycznego ${ }^{4}$ jest kontynuacją myśli Johna Bowlby’ego (1977), który podkreślał zarówno podobieństwa, jak i różnice między nimi. Ten sposób myślenia o przywiązaniu romantycznym jest wciąż aktualny (por. Zeifman, Hazan, 2008) i zostanie zawarty również w niniejszym opracowaniu. Przedstawienie cech wspólnych obu typów więzi zostanie uzupełnione wskazaniem różnic między nimi.

Nie bez znaczenia pozostaje fakt, iż z biegiem czasu w systemie przywiązania dokonuja się liczne przekształcenia. Tłem ich przebiegu są naturalne zmiany zachodzące w jednostce, związane z jej dojrzewaniem i rozwojem w różnych dziedzinach. Uwzględnienie tego wątku w dyskusji jest tak ważne dlatego, że bez niego trudno zrozumieć „przeskok”, jaki dokonuje się w dynamice przywiązania pomiędzy okresem wczesnego dzieciństwa a dorosłością. Można przypuszczać, że prześledzenie reorganizacji zachodzącej w systemie przywiązania w toku poprzedzających wczesną dorosłość stadiów rozwoju pozwoli lepiej zrozumieć podobieństwa i różnice zarysowujące się w opisach stosunków łączących opiekuna i dziecko oraz tych charakteryzujących miłosną relację dorosłych partnerów. W celu uchwycenia istoty przywiązania w relacji miłosnej należy się odwołać do jego początków w najwcześniejszym okresie życia. Dlatego przed przystąpieniem do omówienia przywiązania romantycznego zostanie przedstawiona ontogeneza przywiązania wczesnodziecięcego (dziecka do głównego opiekuna), zwanego również przywiązaniem pierwotnym, jak również przywiązanie w okresie adolescencji. Ten ostatni jest szczególnie istotnym momentem. Charakterystyczny dla niego, stopniowy transfer funkcji przywiązaniowych z rodziców na rówieśników, daje podwaliny do rozwoju przywiązania $\mathrm{w}$ związku miłosnym.

\section{PRZYWIĄZANIE DO GLÓWNEGO OPIEKUNA W PERSPEKTYWIE ROZWOJOWEJ}

Ontogeneza przywiązania jest powolnym procesem obejmującym cztery fazy - trzy pierwsze rozpoczynają się w 1. roku życia dziecka, natomiast czwarta na przełomie 2. i 3. roku życia (Bowlby, 1969/2007; por. Marvin, Britner, 2008). Nie oznacza to, że po wejściu w ostatnią $z$ tych faz w systemie przywiązania nie pojawiają się dalsze modyfikacje. Autor podaje, że choć nie zachodzą już procesy jakościowo odmienne od tych obecnych na czwartym etapie rozwoju systemu przywiązania, dostrzega jednak możliwość zmian ilościowych. Istotne zmiany rozwojowe zachodzą w kilku obszarach: (a) w kompozycji i ustrukturowaniu sieci figur przywiązania, (b) w powiązaniach systemu przywiązania z innymi systemami behawioralnymi, (c) w warunkach aktywacji i wygaszania systemu przywiązania, (d) w formie zachowań przywiązaniowych (wzrost różnorodności ekspresji przywiązania) oraz (e) w reorganizacji w obrębie wewnętrznych modeli operacyjnych przywiązania [WMO] (Marvin, Britner, 2008; Scharf, Mayseless, 2007).

Bowlby (1969/2007) zakładał, że przychodząc na świat, noworodek nie jest przywiązany do żadnej konkretnej osoby. Wrodzony potencjał do tworzenia więzi z innymi ludźmi oraz utrzymywania bliskości z nimi zaczyna się realizować i kształtować dopiero w interakcjach z otoczeniem. Pod ich wpływem dochodzi do znacznego rozwoju zalążkowej postaci wewnętrznego systemu przywiązania (początkowo jest on niezorganizowany i niespecyficzny) (por. Czub, 2005). Wrodzone wyposażenie dzieckazachowania przywiązaniowe - pełnią funkcję przywoływania dorosłych i początkowo nie ma większego znaczenia, kim jest osoba, która na nie odpowie. Sytuacja ta różni się diametralnie od tego, co obserwujemy w okolicach drugiego półrocza życia, kiedy wybrana osoba - figura przywiązania - zostaje wyróżniona spośród grona osób kontaktujących się z dzieckiem. Zajmuje ona szczególne miejsce w jego życiu, na co wskazują następujące zachowania dziecka: (a) preferuje ono jej bliskość i wyraźnie 
poszukuje jej zwłaszcza w chwilach dystresu, nawet jeśli inne osoby są równie osiagalne, (b) silniej protestuje w sytuacji separacji z tą osobą niż z innymi, (c) w nieznanym otoczeniu obecność tej osoby jest bardziej uspokajająca niż obecność innych ludzi. Osoba ta staje się więc główną figurą przywiązania (principal attachment figure; primary caregiver), wokół której organizuje się i na którą jest nakierowany system przywiązania dziecka. Pozostałe ważne dla niego osoby stają się drugoplanowymi figurami przywiązania (secondary attachment figures) (Zeifman, Hazan, 2008). Tę powszechną u dzieci tendencję do wyraźnego faworyzowania jednego opiekuna, szczególnie wtedy, gdy poszukuje ono schronienia, opieki czy ukojenia, Bowlby (1969/2007) określił mianem monotropii.

Zgodnie z perspektywą rozwojową w obrębie ustalonej $\mathrm{w}$ dzieciństwie małej hierarchii głównych figur przywiązania (small hierarchy of major caregivers) (Bretherton, 1980, za: Cassidy, 2008, s.15) dochodzi z czasem do znaczących przemian w strukturze i kompozycji (Zeifman, Hazan, 2008). Przypuszcza się, że rodzic(e) na zawsze pozostaje figurą przywiązania, przestaje jednak odgrywać główną rolę w świecie kontaktów społecznych dziecka, stając się potencjalną/alternatywną figurą wspierającą (Harris, 2002), nazywaną też figurą rezerwową (in reserve) (Weiss, 1991). Oznacza to, że od tej pory, choć pozostaje ona (figura przywiązania) kimś, kogo kochamy, z kim czujemy się emocjonalnie związani i wobec kogo jesteśmy zobowiązani przez całe życie, przestaje jednocześnie być dla nas prymarnym źródłem poczucia bezpieczeństwa. Co więcej, przestaje ona być główną osobą, z pomocą której regulujemy nasze wewnętrzne stany i przeżycia w chwilach trudności ${ }^{5}$. Bowlby (1969/2007) sugerował, iż jej dotychczasowe, najwyższe miejsce w hierarchii ważności figur przywiązania przejmuje partner/partnerka życiowy/a.

\section{ADOLESCENCJA - OKRES PRZEJŚCIOWY}

Momentem przełomowym, w którym następuje inicjacja procesu wycofywania uczuć przywiązaniowych zainwestowanych dotąd $\mathrm{w}$ opiekuna i przekierowywanie ich na rówieśników-partnerów jest wczesna adolescencja (Scharf, Mayseless, 2007; Weiss, 1991; Zeifman, Hazan, 2008).

Miri Scharf i Ofra Mayseless (2007) wskazują na cztery normatywne zmiany w organizacji systemu przywiązania u nastolatków: (1) odwrócenie się od rodziców - tendencja do dystansowania się od nich, (2) zwrot ku innym niż rodzice osobom - inwestycja w relacje rówieśnicze, (3) tworzenie par-budowanie relacji miłosnej z innym dorosłym, (4) większa spójność (zbieżność) i jednocześnie różnicowanie się WMO przywiązania. Podkreślają oni również, iż przebieg rozwoju w aspekcie przywiązania będzie zależny od wewnętrznych modeli operacyjnych ukształtowanych wcześniej, które będa różnie strukturować doświadczenia nastolatków.

Czynnikami inicjującymi te zmiany są: społeczne i seksualne dojrzewanie nastolatka, dostrzeżenie słabości i ograniczeń rodziców (załamanie się idealizacji), większa pewność siebie, większa inwestycja w self oraz rosnąca potrzeba niezależności, autonomii i prywatności u nastolatka. W pewnych sytuacjach czynnikiem spustowym może być dystansowanie się lub odrzucenie ze strony samego rodzica/ów (Scharf, Mayseless, 2007; Weiss, 1991).

Okres adolescencji można potraktować jako fazę przejściową, moment, w którym pojawiają się zaczątki przywiązania romantycznego do rówieśnika-partnera. Relacje miłosne nawiązywane we wczesnej adolescencji są prawdopodobnie częściej motywowane działaniem systemu afiliacji oraz systemu seksualności niż systemu przywiązania (Scharf, Mayseless, 2007). Stworzenie trwałego związku partnerskiego, cechującego się emocjonalnym zaangażowaniem obu stron, jest uważane za główne zadanie rozwojowe dopiero we wczesnej dorosłości (Havighurst, 1981; za: Ziółkowska, 2005).

Jak przebiega proces, w wyniku którego system przywiązania w pełni zmienia swój cel z rodzica na partnera? ${ }^{6}$ Podobnie jak w przypadku relacji dziecko-opiekun, tak i tutaj konsolidacja przywiązania wymaga czasu. Badania przeprowadzone przez Cindy Hazan i Debrę Zeifman (1994), a następnie zreplikowane przez dwa inne zespoły badawcze (Fraley, Davis, 1997; Trinke, Bartholomew, 1994) pozwoliły 
ustalić, że cztery osiowe komponenty definiujące więź przywiązaniową są obecne $u$ adolescentów i osób dorosłych prawie wyłącznie w odniesieniu do rodziców i partnerów miłosnych. Bowlby (1969/2007; por. Weiss, 1991) był zdania, że specyficzne dla przywiązania i odróżniające je od innych, afektywnie nasyconych więzi społecznych są następujące elementy: utrzymywanie bliskości, dystres separacyjny, fenomen bezpiecznej przystani oraz bezpiecznej bazy. Komponenty te stały się punktem wyjścia dla wspomnianych badań przeprowadzonych na różnych grupach wiekowych. Sprawdzano, kogo badani wskazują jako pierwszą/główną osobę spełniającą w ich życiu poszczególne funkcje przywiązaniowe (wywiad WHOTO). Badania z udziałem dzieci oraz adolescentów w wieku 6-17 lat ujawniły interesującą regularność $\mathrm{w}$ transferze tych funkcji z rodziców na rówieśników w toku kolejnych okresów rozwojowych? Niemal cała grupa badawcza (zarówno dzieci, jak i adolescenci) wykazała zdecydowaną preferencję rówieśników pod względem pierwszego z wymienionych przejawów przywiązania, czyli poszukiwania bliskości. Pomiędzy 8. a 14. rokiem życia rówieśnicy częściej niż rodzice zaczynają być także głównym źródłem pocieszenia i wsparcia emocjonalnego (funkcja bezpiecznej przystani). Pomimo przekierowania części zachowań przywiązaniowych na rówieśników rodzice nadal odgrywają główną rolę, jeśli chodzi o funkcje bezpiecznej bazy, a rozłąka z nimi prowadzi do przeżywania lęku separacyjnego. Relacja z rodzicami przenika mniej aspektów życia nastolatka (Ainsworth, 1989), zmniejsza się jej intensywność w znaczeniu poszukiwania ich pomocy, spędzania wspólnie czasu i okazywania sobie uczuć w sposób fizyczny oraz cechuje ją większa równorzędność i wzajemność niż dotychczas.

Pomimo rosnącego dystansu i niezależności emocjonalnej od rodziców relacja z nimi pozostaje nadal ważna w sensie przywiązaniowym (Scharf, Mayseless, 2007; por. Liberska, Głogowska, Deja, 2016). Ciekawych dowodów na to dostarczają badania przywiązaniowego stanu umysłu za pomocą wywiadu Adult Attachment Interview (Ammaniti, van Ijzendoorn, Speranza, Tambelli, 2000; Scharf, 2001; Scharf,
Mayseless, Kivenson-Baron, 2004, za: Liberska, Głogowska, Deja, 2016). Wynika z nich, że nastolatki w wieku 10-14 lat wypowiadaja się o relacjach z rodzicami w mniej ciepłym tonie, z mniejszym niż dotychczas sentymentem, a niekiedy wręcz $\mathrm{z}$ pewną dozą lekceważenia i umniejszania ich znaczenia. Spostrzegają też rodziców jako bardziej odrzucających. Jednocześnie spójność ich dyskursu o tej relacji pozostaje wysoka, co wskazuje na autonomiczny, a wobec tego dający poczucie bezpieczeństwa przywiązaniowy stan umysłu. Jakość przywiązania zmienia się jedynie pozornie. Co więcej, obserwowany spadek ważności rodziców jako figur przywiązania jest zazwyczaj tymczasowy. Po okresie wzmacniania swojego poczucia niezależności od rodziców młody dorosły może na powrót obsadzić rodzica w roli osoby, na której pomoc i wsparcie chętnie liczy. Mimo to ten rodzaj zależności i ponownej inwestycji w relację z nim nie jest już tak wyłączny jak poprzednio zostaje niejako rozluźniony dzięki obecności innych figur przywiązania w życiu jednostki.

Dopiero w grupie wiekowej 15-17 lat zaobserwowano, że rówieśnicy są wskazywani jako osoby pełniące dwie kolejne funkcje: są głównym źródłem poczucia bezpieczeństwa pozwalającego na podejmowanie innych działań, na przykład eksploracyjnych (funkcja bezpiecznej bazy), a faktyczna lub antycypowana rozłąka z nimi prowadzi do lęku separacyjnego, większego niż w sytuacji rozłąki z rodzicami. Natalie Rosenthal i Roger Kobak (2010) zwracają jednak uwagę na konceptualizację więzi przywiązaniowej i jej operacjonalizację w ujęciu Hazan i Zeifman. Zdaniem autorów poszukiwanie bliskości zoperacjonalizowane w WHOTO w postaci stwierdzeń: chce spędzać czas z ta osoba, może być motywowane nie tylko aktywacją systemu przywiązania. U podstaw takiego zachowania mogą występować motywy afiliacyjne lub seksualne. Podobnie poszukiwanie wsparcia w sytuacjach niezagrażających jednostce lub relacji z drugą osobą, które nie stanowią sygnałów aktywujących system przywiązania, tj. do kogo się zwracasz, kiedy jesteś przygnębiony, nie pozwala ocenić preferencji odnośnie do figur przywiązania. $Z$ tego powodu te dwa aspekty, ich zdaniem, nie wskazuja 
jeszcze na obecność więzi przywiązaniowej. Za bardziej trafne uznają oni itemy odnoszące się do bezpiecznej bazy, tj. jest to ktoś, na kogo moge zawsze liczyć oraz te wskazujące na dystres separacyjny: jest to ktoś, za kim tęsknię.

Rosenthal i Kobak (2010) zaproponowali własny sposób oceny hierarchii figur przywiązania u adolescentów, pozwalający dodatkowo na odróżnienie figur przywiązania od innych osób składających się na sieć wsparcia nastolatka (Important People Interview). $\mathrm{Z}$ badań, w których wykorzystali opracowaną przez siebie metodę, wynika, że młodzież w sytuacjach mniej alarmujących, rodzących mniejszy dystres, związanych raczej ze stresem o charakterze codziennym, po emocjonalne wsparcie zwraca się chętniej do rówieśników niż do rodziców. W sytuacjach alarmujących, czyli zagrożenia lub dystresu separacyjnego, rodzice pozostają często najważniejszymi figurami przywiązania nastolatków. Transfer funkcji przywiązaniowych od dzieciństwa do wczesnej dorosłości prezentuje tabela 1.

Warto nadmienić, że we wspomnianych badaniach zdecydowana większość rówieśniczych relacji, w których uformowała się więź przywiązaniowa, stanowiły relacje z chłopakiem lub dziewczyna - relacje romantyczne, a nie przyjacielskie. W przyjaźniach zawieranych w okresie adolescencji rzadko obecne są wszystkie komponenty w pełni wykształconej relacji przywiązania (Scharf, Mayseless, 2007), co przekłada się między innymi na ich niestabilność. Zdaniem Mary Ainsworth (1989) więź przyjacielska zwykle nie dorównuje trwałością więziom łączącym nastolatków z osobami spokrewnionymi, nawet wówczas, gdy te drugie wzbudzaja ambiwalentne uczucia. Jakie jest zatem znaczenie tych przyjaźni z perspektywy rozwoju systemu przywiązania? Scharf i Maysaless (2007) wymieniają trzy takie funkcje. Przyjaciele sąźródłem wsparcia o charakterze emocjonalnym i instrumentalnym oraz pomagają nastolatkom radzić sobie $\mathrm{z}$ dystresem, co ułatwia separację $z$ rodzicami i wzmacnia autonomię. Ze względu na większą symetryczność tych relacji w porównaniu z relacjami z rodzicami daja możliwość ćwiczenia się w bardziej wzajemnym i partnerskim układzie. W tej relacji obie strony wymiennie otrzymują i dostarczają wsparcie, troskę i ochronę. Taka wzajemność jest niezbędna do stworzenia partnerskiego związku w przyszłości (por. Czubak, 2018). Stają się również okazją do rozwijania umiejętności współpracy i postawy altruizmu w relacji (Furman, 2001). Ponadto powiększenie liczby potencjalnie dostępnych figur przywiązania o przyjaciół zapewnia większą elastyczność $\mathrm{w}$ radzeniu sobie ze stresem. Takie „rozproszenie” przywiązania jest również korzystne, jeśli pamiętamy o tym, że nastolatek rzadko pozostaje wierny swoim

Tabela 1. Transfer funkcji przywiązaniowych od dzieciństwa do wczesnej dorosłości

\begin{tabular}{|c|c|c|}
\hline Okres przed adolescencją & Wczesna adolescencja & $\begin{array}{l}\text { Późna adolescencja - } \\
\text { wczesna dorosłość }\end{array}$ \\
\hline Rodzice & Rodzice & \\
\hline \multirow{3}{*}{$\begin{array}{l}\text { - poszukiwanie bliskości } \\
\text { - bezpieczna przystań } \\
\text { - protest separacyjny } \\
\text { - bezpieczna baza }\end{array}$} & $\begin{array}{l}\text { - protest separacyjny } \\
\text { - bezpieczna baza }\end{array}$ & \\
\hline & Rówieśnicy & Rówieśnicy \\
\hline & $\begin{array}{l}\text { - poszukiwanie bliskości } \\
\text { - bezpieczna przystań }\end{array}$ & $\begin{array}{l}\text { - poszukiwanie bliskości } \\
\text { - bezpieczna przystań } \\
\text { - protest separacyjny } \\
\text { - bezpieczna baza }\end{array}$ \\
\hline
\end{tabular}

Źródło: opracowanie własne na podstawie Scharf, Mayseless (2007); Rosenthal, Kobak (2010). 
wyborom, a jego związki z ludźmi są tyleż intensywne, ile nietrwałe. Zaangażowanie emocjonalne jednocześnie $\mathrm{w}$ kilka relacji - w tym z mentorami, autorytetami, idolami - wydaje się adaptacyjne z punktu widzenia niestałości uczuć nastolatka. Na wypadek zerwania relacji pozostają bowiem jeszcze te drugoplanowe, pomocnicze figury przywiązania (secondary or supplementary attachment figures), choćby w symbolicznym wymiarze, jak na przykład wspomniani idole.

$\mathrm{W}$ adolescencji zadaniem rozwojowym w obszarze przywiązania według Scharf i Mayseless (2007) jest, po pierwsze, osłabienie znaczenia więzi przywiązaniowych dla przetrwania jednostki oraz, po drugie, większa dywersyfikacja inwestycji emocjonalnych wkładanych $w$ relacje $z$ innymi. Dywersyfikacja ta przejawia się w zwiększonej liczbie figur przywiązania; stają się one mniej centralnym aspektem w życiu jednostki, dochodzi też do ich specjalizacji w zakresie poszukiwania wsparcia, zależnie od kontekstu i sytuacji (np. nastolatek może zwracać się do mamy, kiedy jest chory fizycznie, a do przyjaciela, kiedy czuje się samotny).

\section{ROZWÓJ PRZYWIAZZANIA W ZWIĄZKU MILOSNYM}

Wspomniane już Hazan i Zeifman (1994) postanowiły zweryfikować empirycznie również kwestię ustanawiania relacji przywiązaniowej w czasowej perspektywie trwania relacji romantycznej. W tym celu zastosowały identyczną jak poprzednio procedurę badawcza, tym razem w odniesieniu do osób dorosłych w wieku 18-82 lat, podzielonych na trzy grupy porównawcze: osoby niebędące aktualnie w związku, osoby będące w związku krócej niż dwa lata oraz osoby zaangażowane w relację miłosną od minimum dwóch lat. Okazało się, że przebieg procesu formowania się przywiązania jest zależny od długości trwania związku. W początkowej fazie dominuje preferowanie bliskości i kontaktu z partnerem. Potrzeba wsparcia i opieki występuje dopiero na późniejszym etapie trwania związku. W ostatniej kolejności pojawia się reakcja na separację z partnerem, który pełni również funkcję „,bezpiecznej bazy”. Dotyczy to przede wszystkim osób z co najmniej dwuletnim stażem związku. W przypadku osób z dwóch pozostałych grup porównawczych źródłem poczucia bezpieczeństwa i lęku separacyjnego okazali się przede wszystkim rodzice. Opisywane dane empiryczne wskazują, że romantyczny związek zyskuje w pełni przywiązaniowy charakter około drugiego roku jego trwania. Z kolei w nowszych badaniach wykazano, że transfer ten zachodzi znacznie wcześniej i już po roku trwania relacji może stać się ona w pełni przywiązaniowa (Heffernan, Fraley, Vicary, Brumbaugh i in., 2012). Zagadnienie to wymaga dalszych badań.

Hazan i Zeifman $(1994,1997)$ postulują, że fazy procesu, który udało im się zidentyfikować w zaprezentowanych badaniach, odzwierciedlają sekwencyjność ontogenezy przywiązania u dzieci. Pierwsza faza preprzywiązaniowa u niemowląt przypomina flirtujące zachowania młodych dorosłych poszukujących partnera w tym sensie, że są niespecyficznie uruchamiane w kontaktach $\mathrm{z}$ różnymi osobami, a żadna $\mathrm{z}$ nich nie jest jeszcze ważniejsza od pozostałych. $Z$ czasem atrakcyjność seksualna i/lub romantyczne zainteresowanie drugą osobą powodują że jednostka dąży do podtrzymania kontaktu $\mathrm{z}$ nią $\mathrm{i}$ w tym sensie możemy już mówić o selektywnym poszukiwaniu bliskości z jedną wybraną osobą. $\mathrm{Na}$ tym etapie nie są obecne inne formy zachowań przywiązaniowych, a poszukiwanie bliskości nie pełni jeszcze funkcji redukcji napięcia i dyskomfortu oraz nie jest uruchamiane w sytuacji dystresu. Wyraża raczej zainteresowanie drugą osobą, której obecność jest silnie pobudzająca dla jednostki. Kiedy flirt przerodzi się w ,zauroczenie", takie zachowania, jak wpatrywanie się w drugą osobę, przedłużający się dotyk, przytulanie się itd. zaczynają być kierowane do tej wybranej osoby i są przez nią odwzajemniane, a interakcje te są podobne do diadycznych wymian pomiędzy matką a dzieckiem na etapie nazywanym ,przywiązaniem w trakcie formowania się" (attachment-in-the-making). W tym okresie zasadniczą cechą wzajemnych stosunków w parze jest intensywny kontakt fizyczny. Poprzez bliskość fizyczną partnerzy zaczynają uzyskiwać już nie tylko pobudzenie, ale także uspokojenie (funkcja bezpiecznej przystani). W fazie trzeciej, 
skonsolidowanego przywiązania, we wzajemnych kontaktach dziecka z opiekunem zarysowują się następujące cechy: aktywne utrzymywanie bliskości, lęk separacyjny, fenomen bezpiecznej przystani i bezpiecznej bazy. Po pewnym czasie od momentu rozpoczęcia związku podobny zestaw cech obserwujemy w relacji dorosłych, traktując to jako dowód na uformowanie się przywiązania. Przebywanie z partnerem nie jest już tak ekscytujące jak początkowo, a potrzeba kontaktu fizycznego staje się mniej intensywna. Dzięki powtarzającym się epizodom wzajemnego opiekowania się sobą partner zyskuje uprzywilejowaną pozycję jako preferowane źródło wsparcia, a w związku z tym jego nieobecność rodzi dyskomfort i osłabia poczucie bezpieczeństwa. Partner staje się centralnym „węzłem" w sieci wsparcia jednostki, a przekonanie o trwałości związku sprawia, że wkracza on w czwartą fazę - partnerstwa korygowanego przez cel (goal-corrected partnership) - w której dochodzi do znaczącego zmniejszenia się ilości jawnej ekspresji zachowań przywiązaniowych. Owocem dotychczasowych interakcji partnerów, przebiegających w przyjaznej atmosferze oraz pełnych opiekuńczości, jest wytworzenie się przekonania o stałej dostępności drugiej osoby, a związany z tym względnie stabilny stan poczucia bezpieczeństwa pozwala jednostce skierować uwagę na zewnątrz związku, ku innym wyzwaniom i obowiązkom. Robert Weiss (1991, s.73, thum. własne) tak opisuje to stadium:

Dorośli, podobnie jak dzieci przywiązane bezpiecznie, nie koncentrują swojej uwagi na figurze przywiązania. Siedzącą w restauracji parę, której wzajemne przywiązanie trwa już czas jakiś, najłatwiej poznać po obopólnym zrelaksowaniu, pozbawionym tak charakterystycznej dla okresu zalotów intensywnej, wzajemnej atencji partnerów. Taka para nie jest w siebie głęboko zapatrzona, jak dawniej. Zamiast tego prowadzi ze sobą przyjazną, być może lekko pobieżną rozmowę, zerkając na siebie jedynie od czasu do czasu, a zwykle spoglądając w innym kierunku. Zamiast wsłuchiwać się w siebie z niezwykłą uwagą, partnerzy pozwalają sobie na swobodną dystrakcję. Nie szukają okazji do dotyku, a kiedy ten już się pojawia, nie niesie ze sobą tego samego ładunku co kiedyś. Krótko mówiąc, ludzie ci wyglądają jak małżeńska para. Tym właśnie jest prawdziwe przywiązanie - funkcjonuje jak stabilna baza.

\section{PRZEJAWY PRZYWIĄZANIA ROMANTYCZNEGO}

Wyodrębnienie listy markerów przywiązania romantycznego wydaje się ważne głównie z przyczyn praktycznych, jako podstawa do orzekania o wytworzonej w relacji dwojga więzi przywiązaniowej ${ }^{8}$. Istnieje kilka czynników utrudniających empiryczną identyfikację cech definicyjnych w pełni ukształtowanego przywiązania (Hazan, Gur-Yaish, Campa, 2004). Po pierwsze, nie należy ignorować wpływu różnic indywidualnych na odchylenia od przyjmowanego prototypu, który z założenia normalizuje uniwersalne aspekty przywiązania. Funkcjonowanie osób o przywiązaniu bezpiecznym jest stałym punktem odniesienia w badaniach nad normatywnym aspektem teorii przywiązania. Wzorce pozabezpieczne sa traktowane jako przypadki od niego odbiegające. Pamiętając, że właściwa im organizacja systemu przywiązania wiąże się chociażby z określonym stylem ekspresji potrzeb przywiązaniowych, za najbardziej kłopotliwy w tym kontekście należałoby uznać styl unikający, ponieważ spośród pozostałych wyróżnia go hamowanie ekspresji systemu przywiązania na różnych poziomach, a w tej sytuacji dość łatwo pomylić go $\mathrm{z}$ brakiem przywiązania. Ciekawego opisu sekwencyjnego rozwoju wzorców przywiązania, w którym został podkreślony wzrost zróżnicowania tych wzorców w kolejnych okresach rozwojowych, dokonał Zbigniew Łoś (2010). Postuluje on konieczność uwzględnienia trzech wymiarów relacji interpersonalnej $\mathrm{w}$ celu scharakteryzowania różnic indywidualnych w przywiązaniu osób dorosłych: zaufanie-nieufność, zależność-niezależność, submisja-dominacja.

Po drugie, charakteryzowanie przywiązaniowej więzi łączącej dorosłych partnerów odbywa się zwykle poprzez nawiązanie do opisu właściwości przywiązania pierwotnego (por. np. Shaver, Hazan, Bradshaw, 1988; Weiss, 1991). Badacze tego problemu nie są jednomyślni, na 
ogół jednak wymieniają podobny zestaw centralnych właściwości przywiązania, obecnych niezależnie od wieku człowieka, które można podzielić na dwie grupy. Pierwsza z nich odnosi się do rozumienia przywiązania w kategoriach systemu behawioralnego, druga jest związana $\mathrm{z}$ definiowaniem przywiązania w kategoriach uczuciowego związku istniejącego między dwiema jednostkami.

Pierwsza wspomniana grupa cech przywiązania obejmuje następujące elementy: dążenie do bliskości, efekt bezpiecznej bazy i bezpiecznej przystani oraz czynniki aktywujące system przywiązania. Zostaną one po kolei omówione.

Biorąc pod uwagę dążenie do fizycznej bliskości z figurą przywiązania, należy zauważyć, że o ile niemowlę bezwzględnie potrzebuje fizycznej obecności opiekuna, o tyle dorosłym wystarczy sama myśl o tym, że mają w swoim życiu ukochaną osobę, nawet jeśli nie jest ona fizycznie obecna. Dlatego dorosły człowiek rzadziej poszukuje bezpośredniej bliskości swoich figur przywiązania, co nie świadczy jednak o braku przywiązania. Szczególnie cenne są w tym kontekście doniesienia oparte na naturalistycznych obserwacjach zachowań oraz te wykorzystujacce procedury eksperymentalne. Warto przytoczyć tutaj chociażby badania Chrisa Fraleya i Shavera (1998), którzy obserwowali pary na lotnisku. Część z nich udawała się na wspólną wycieczkę, część żegnała się ze sobą, gdyż tylko jeden z partnerów wybierał się w podróż. Wyniki tych obserwacji potwierdzają tendencję do nasilania ekspresji zachowań przywiązaniowych (tj. przytulanie, trzymanie się za ręce, obdarzanie pocałunkami) w obliczu czekającej partnerów rozłąki. Zależność ta nie była jednak bezwarunkowa, lecz tym silniejsza, im krótszy był staż związku obserwowanych osób. Oznacza to, że dorośli, podobnie jak dzieci w fazie ,partnerstwa korygowanego przez cel”, sa zdolni do wytrzymywania krótkotrwałej rozłąki z figura przywiązania, bez przeżywania przy tym wyraźnego dystresu. W takich sytuacjach ich wewnętrzny spokój jest tym większy, im bardziej skonsolidowane jest ich przywiązanie.

Ważnym wyrazem obecności komponenty przywiązaniowej w relacji jest poszukiwanie bliskości partnera w dystresie (efekt bezpiecz- nej przystani). Badania zgodnie pokazują, że dorośli ludzie w trudnych chwilach poszukują bliskości ukochanych osób, a ich obecność działa jak ,antidotum” na stres, lęki i wszelkie stany przykrego napięcia (Mikulincer, Shaver, 2007). Związek miłosny z perspektywy teorii przywiązania jest nie tylko „ratunkiem” w kryzysie. Pewność, że w naszym życiu jest ktoś, komu możemy ufać, kto zawsze służy nam pomocą, działa - mówiąc metaforycznie - jak „zastrzyk odwagi”, który pozwala oddalać się od tej osoby w poszukiwaniu wyzwań, dzięki którym dokonuje się nasz rozwój osobisty (efekt bezpiecznej bazy eksploracji). Za obszar, w którym dorośli podejmują działania eksploracyjne, uznaje się zwykle aktywność zawodową (Hazan, Shaver, 1990). Na poziomie poznawczym efekt bezpiecznej przystani i bezpiecznej bazy manifestuje się tym, że reprezentacja osoby będącej naszą główną figurą przywiązania jest automatycznie przywoływana w umyśle w momencie percepcji zagrożenia, a proces ten zachodzi często bez naszej świadomości (Mikulincer, Gillath, Shaver, 2002).

Do czynników aktywujących system przywiązania w dorosłości można zaliczyć zagrożenia fizyczne i psychologiczne, stresory o różnym natężeniu, czyli jakakolwiek nieznana sytuacja, wiadomość o ciężkiej chorobie, informacja o katastrofie naturalnej, samotność czy wzbudzające zazdrość pojawienie się atrakcyjnej kobiety lub mężczyzny w pobliżu partnera/partnerki, a także zdarzenia potencjalnie pozytywne, na przykład ciąża (Mikulincer, Shaver, 2007; Ainsworth, 1991). Spośród nich wyraźnie stresującą sytuacjąjest ta, w której zostaje zagrożona zazwyczaj obecna, ciagła dostępność figury przywiązania, uruchamiając protest separacyjny (Weiss, 1991). Bez wattpienia kolejnym wyjątkowo silnym stresorem jest utrata figury przywiązania na skutek śmierci lub rozwodu. Wzorzec reakcji człowieka dorosłego na stratę bliskiej osoby przypomina reakcję dziecka, które utraciło matkę i obejmuje podobne fazy, czyli protest, rozpacz i fazę pozornego zerwania więzi (Bowlby, 1988).

Kiedy analizujemy drugą ze wspomnianych grup właściwości przywiązania, wówczas na plan pierwszy wysuwa się podkreślana przez Weissa (1991) wyjątkowa ważność i specyficzność 
figury przywiązania, która stanowi dla jednostki niezastępowalne (lub trudne do zastapienia przez inne osoby) źródło poczucia bezpieczeństwa. Zdaniem autora wyraźnym dowodem na trwałość tej więzi jest intensywna tęsknota pojawiająca się w momencie przedłużającej się rozłąki, która słabnie powoli i nigdy nie znika do końca. Z kolei protest separacyjny utrzymuje się nawet w sytuacji, gdy osoba zdaje sobie sprawę z tego, że powrót figury przywiązania nie jest możliwy (np. z powodu jej śmierci), a dostępność innych źródeł wsparcia (w postaci drugoplanowych figur przywiązania) nie rekompensuje tej straty. O stałości więzi przywiązaniowej świadczy również fakt, że trwa ona pomimo braku wzmocnień i nie zanika na drodze habituacji (Weiss, 1991, s. 67). Ponadto jest „odporna” na negatywne doświadczenia (można ją nawiązać $\mathrm{z}$ osobą, która jest krzywdząca, zaniedbująca czy upokarzająca). Z tej perspektywy wyraźnie widać, że przywiązanie różni się od innych więzi uczuciowych (affectional bonds), jakie nawiazujemy z ludźmi (Ainsworth, 1989). Ainsworth (1989) wymienia trzy cechy odróżniające więzi uczuciowe od związku: (a) więź trwa zwykle stosunkowo długo; związek może, lecz nie musi być długotrwały, (b) związek ma naturę diadyczna, a więź uczuciowa to coś, co rozwija jednostka, co ma charakter wewnętrznej reprezentacji, (c) natura związku między dwojgiem ludzi jest zdeterminowana całościowo przez historię interakcji, jakie zachodziły między nimi i z tego powodu zawiera w sobie rozmaite komponenty, nie tylko przywiązaniowe czy uczuciowe. Autorka definiuje ,więź uczuciową” jako (Ainsworth, 1989, s. 711, tłum. własne)

[...] relatywnie długotrwałą więź, w której ważność partnera czyni go wyjątkową osobą, której nikt inny nie może zastąpić. Więź ta odpowiada za pragnienie utrzymania bliskości z partnerem. U starszych dzieci i osób dorosłych bliskość tę można podtrzymywać do pewnego stopnia w czasie i przestrzeni oraz podczas nieobecności drugiej osoby, ale sporadycznie i tak zawsze jest wówczas obecne pragnienie, aby odnowić bliskość i interakcję, a ponownemu spotkaniu towarzyszy przyjemność, często radość. Rozłąki, które następują bez wyjaśnienia, powodują dystres, a całkowita utrata więzi skutkuje żałobą.

Cechy świadczące o wytworzeniu się więzi przywiązaniowej w relacji dorosłych partnerów prezentuje tabela 2 .

Tabela 2. Cechy świadczące o wytworzeniu się więzi przywiązaniowej w relacji dorosłych partnerów

- Poszukiwanie i pragnienie bliskości - fizyczna bliskość partnera wiąże się z przyjemnością oraz przywraca komfort w sytuacji dystresu.

- Efekt bezpiecznej przystani - poszukiwanie figury przywiązania w chwilach dystresu, szczególnie o dużym natężeniu; odzyskiwanie równowagi emocjonalnej i redukcja dystresu z pomocą partnera; poczucie bezpieczeństwa i komfortu uzyskiwane poprzez relację przywiązaniową i obecność figury przywiązania.

- Efekt bezpiecznej bazy - podejmowanie działań eksploracyjnych dzięki poczuciu bezpieczeństwa, jakie zapewnia relacja z partnerem/partnerka.

- Protest separacyjny; żałoba po stracie partnera - silna reakcja na ryzyko utraty lub na stratę partnera/partnerki; dystres w sytuacji niewyjaśnionej rozłąki.

- Utworzenie WMO relacji przywiązania - partner/partnerka i relacja z nim/nią są centralnym elementem w poznawczej mapie świata społecznego jednostki.

- Uczuciowość kierowana ku partnerowi - osoba partnera oraz interakcje z nim wzbudzają silne emocje, na przykład radość i przyjemność podczas ponownego spotkania po rozłące.

- Specyficzność figury przywiązania i trwalość więzi z nią - figura przywiązania, z którą więź jest emocjonalnie znacząca dla podmiotu, nie daje się nigdy w pełni zastąpić przez inną; więź ta jest długotrwała.

Źródło: opracowanie własne na podstawie Ainsworth (1989); Bowlby (1969/2007); Hazan, Campa, Gur-

-Yaish (2006), Weiss (1991). 
Opisując tworzenie się przywiązania w dzieciństwie, Bowlby posłużył się metaforą zakochania. Podkreślał jego uczuciową naturę takimi oto słowami (Bowlby, 1969, s. 209, thum. za: Stawicka, 2008):

Żadnej innej formie zachowania nie towarzyszą tak silne uczucia, jak to jest w przypadku zachowania przywiązaniowego. Figury, do których jest ono kierowane, są obdarzane miłością (są kochane), a ich pojawienie się jest związane z radością. Tak długo, jak dziecko znajduje się w niezagrożonej niczym bliskości z opiekunem, czuje się bezpieczne. Zagrożenie utratą tej bliskości wzbudza lęk, faktyczna utrata - smutek, oba zdarzenia zaś wywołują złość.

Do tej szerokiej gamy uczuć wzbudzanych przez obiekt przywiązania dodać można zazdrość i żałobę po stracie (Ainsworth, Blehar, Waters, Wall, 1978). Wydaje się, że relację miłosną dwojga dorosłych osób można by scharakteryzować w podobny sposób, co sugeruje jej przywiązaniowy charakter.

Warto jeszcze dodać, że kryterium specyficznym dla więzi przywiązaniowej, różnicującym ją od innych typów więzi emocjonalnych, jest funkcja bezpiecznej bazy i bezpiecznej przystani. Więzi uczuciowe niemające charakteru przywiązaniowego zwykle nie pełnią tych funkcji.

Znalezienie paraleli pomiędzy przywiązaniem dziecięcym a przywiązaniem dorosłych nie jest trudne. Przejdźmy teraz do wskazania różnic. Miłość romantyczna jest opisywana jako integracja trzech behawioralnych systemów: seksualności, przywiązania i opiekuńczości (Ainsworth, 1990; Bowlby, 1969/2007; Fraley, Shaver, 2000; Hazan, Shaver, 1994; Mikulincer, Goodman, 2006). Uwzględnienie łącznego wpływu tych systemów pozwala zrozumieć specyfikę romantycznych relacji w porównaniu z przywiązaniem dziecięcym. Poszukiwanie bliskości fizycznej w przypadku dorosłego pozostającego $\mathrm{w}$ relacji $\mathrm{z}$ drugim dorosłym jest motywowane nie tylko, jak w przypadku niemowlęcia czy dziecka, poszukiwaniem schronienia w sytuacji zagrożenia lub niezaspokojonymi potrzebami, lecz również atrakcyjnością seksualną, szczególnie w początkowych etapach formowania się związku (Zeifman, Hazan, 2008) lub chęcią udzielenia pomocy partnerowi (Hazan, Shaver, 1994). Specyfika bliskich związków dorosłych ludzi polega na tym, że pod wieloma względami są one bardziej symetryczne niż relacja dziecko-rodzic. Partnerzy romantyczni pełnią względem siebie wymiennie funkcje figur przywiązania (Ainsworth, 1985; 1991; Crowell, Treboux, 1995, Zeifman, Hazan, 2008). Kolejna przytaczana w literaturze cecha odróżniająca relacje romantyczne od relacji dziecko-opiekun dotyczy genetyki: partnerzy romantyczni nie sa biologicznie spokrewnieni i przypuszczalnie z tego powodu zakłada się, że więź, jaka ich łączy, rzadko dorównuje pod względem trwałości i siły, więzi istniejącej między dzieckiem a opiekunem (Hazan, Shaver, 1994). Jak podają Zeifman i Hazan (2008), choć łączenie się w pary jest regulowane przez system przywiązania, to jednak powstająca w jego rezultacie więź z osobą dorosłą może być mniej trwała i jest bardziej podatna na rozpad (np. rozwód) niż przywiązanie dziecka do pierwotnego opiekuna. Mimo to, jak wspomniano wcześniej, wskazuje się, że tylko w dwóch typach relacji występuje podobny wzorzec reakcji na utratę bliskiej osoby: w relacji niemowlę-opiekun oraz w związku miłosnym dorosłej pary. Z kolei w sytuacji rozstania partnerów, nawet jeśli było ono pożądane, pozostaje tęsknota i poczucie osamotnienia, wskazujące na ważność tej relacji (Weiss, 1973).

\section{PODSUMOWANIE}

Przywiązanie w relacji romantycznej rozwija się stopniowo i zanim nastąpi jego ,pełen rozkwit" (full-blown attachment), zwykliśmy polegać na osobach, które do tej pory odgrywały w naszym życiu rolę figur przywiązania. Obecna w związku miłosnym komponenta przywiązaniowa decyduje o szczególnym charakterze więzi, jaka łączy nas z partnerem/partnerką. Nie jest ona tym samym, co wierność lub długoletnie zaangażowanie. Jej zasadnicze cechy są analogiczne do relacji dziecko-opiekun, choć występują też istotne różnice wynikające z faktu integracji trzech wspomnianych systemów 
behawioralnych w dorosłości, z których dwa nie są jeszcze obecne w dzieciństwie. Ewolucyjną funkcją przywiązania $\mathrm{w}$ dorosłości pozostaje umożliwienie przetrwania (z uwagi na zdolność do samoregulacji osoby dorosłej w mniejszym stopniu niż w dzieciństwie) i sukces reprodukcyjny. Funkcja psychologiczna jest również niezmienna: więzi te warunkują nasze zdrowie i dobrostan psychiczny.

Wiedza o wskaźnikach wytworzonego przywiązania ma zarówno walor badawczy, jak i praktyczny. Umożliwia odróżnienie więzi uczuciowych o charakterze przywiązania od pozostałych więzi społecznych. Z badawczego punktu widzenia wiedza o wskaźnikach wytworzonego w dorosłości przywiązania romantycznego i przebieg jego rozwoju wydają się kluczowe, choć bywają przez badaczy pomijane; a priori przyjmuje się założenie, że każda bliska relacja jest przywiązaniem. Bywa, że relacje o krótkim stażu trwania są traktowane jako przywiązaniowe, co stawia pod znakiem zapytania wnioski wyciagane z badań, w których wytworzenie się więzi przywiązaniowej nie jest kontrolowane, a każda relacja romantyczna traktowana jest a priori jako przywiązaniowa. W dziedzinie praktyki, na przykład psychoterapeutycznej, wiedza ta może się okazać przydatna $\mathrm{w}$ aspekcie diagnostycznym oraz może wspomagać monitorowanie tworzenia się więzi w relacji terapeutycznej i dynamikę przymierza terapeutycznego.

Opisane w artykule mechanizmy tworzenia przywiązania $\mathrm{w}$ związku romantycznym domagają się dalszej weryfikacji empirycznej. Problematyczne pozostaje wskaźnikowanie przywiązania pozabezpiecznego. Z uwagi na wartość aplikacyjną tej wiedzy kolejne badania w tej dziedzinie są niezbędne. Konieczne wydaje się też częstsze uwzględnianie jej przez badaczy przywiązania.

\section{PRZYPISY}

${ }^{1}$ Artykuł dofinansowany przez grant promotorski MNiSW nr NN106 030238.

2 „Romantic love conceptualized as an attachment process”.

${ }^{3}$ Stanowisko autorów jest odpowiedzią na niezadowalające ich zdaniem ówczesne opracowania na temat miłości, samotności i żałoby w toku życia człowieka. Warto dodać, że sami autorzy podkreślają zalaż̇owy charakter tej pracy, co przypomną kilka lat później w artykule z 1994 roku, dystansując się od niektórych wyrażonych wówczas stwierdzeń.

${ }^{4} \mathrm{~W}$ literaturze anglojęzycznej funkcjonuje zwrot romantic attachment. Jego dosłowny przekład - jako ,przywiązanie romantyczne" - jest wygodny językowo i będzie stosowany w niniejszym artykule. Bardziej poprawnym znaczeniowo rozwinięciem tego skróconego sformułowania byłoby ,przywiązanie występujące w relacji romantycznej" (pomiędzy partnerami związku miłosnego).

${ }^{5}$ Weiss (1991), powołując się na badania Perlmana (1988), twierdzi, że okres obejmujący późną adolescencję i wczesną dorosłość jest takim czasem w życiu człowieka jak wtedy, kiedy jest on najbardziej narażony na „dojmująco bolesną samotność”. Dzieje się tak dlatego, że system przywiązania jest w fazie transformacji - rodzic przestaje być obiektem, na który nakierowane są dążenia bliskościowe, a jednocześnie brakuje wypełniającej tę pustkę, nowej figury przywiązania, której obecność pozwoliłaby odzyskać chwilowo utracone poczucie bezpieczeństwa.

${ }^{6}$ Osoby, które nie nawiązują bliskich związków, traktują rodzica/rodziców jako pierwszą w hierarchii figurę przywiązania.

${ }^{7}$ Badacze byli zainteresowani głównie różnicami pomiędzy rodzicami a rówieśnikami w roli figur przywiązania, dlatego wnioski z badań odnoszą się tylko do tych dwóch kategorii bliskich osób.

${ }^{8}$ Ten aspekt w odniesieniu do romantycznego przywiązania pozostawał dość długo zaniedbany w porównaniu z zagadnieniem różnic indywidualnych. Pierwsze doniesienia empiryczne na temat przywiązania dorosłych dotyczyły głównie stylów przywiązania i ich korelatów (Hazan, Campa, Gur-Yaish, 2006). Wśród opracowań poświęconych analizie markerów przywiązania w dorosłości dominowały początkowo czysto teoretyczne rozważania (zob. Hazan, Gur-Yaish, Campa, 2004; Shaver, Hazan, Bradshaw, 1988). Z kolei podejmowane badania, jak np. przytoczona praca Hazan i Zeifman (1994), wykorzystują najczęściej opracowaną przez 
autorów metodę samoopisową, odnoszącą się jedynie do czterech wskazanych przez Bowlby'ego aspektów przywiązania. W doniesieniach opartych na metodach eksperymentalnych lub obserwacyjnych rzadko podejmuje się tę tematykę, a referowane ustalenia są zwykle produktem ubocznym w stosunku do głównego celu badań i niejednokrotnie mają wybiórczy charakter (odnoszą się tylko do jednego lub dwóch wskaźników przywiązania). Brakuje systematycznych badań w tym zakresie.

\section{BIBLIOGRAFIA}

Ainsworth M.D.S. (1985), Patterns of infant-mother attachments: Antecedents and effects on development. Bulletin of the New York Academy of Medicine, 61(9), 771-791.

Ainsworth M.D.S. (1989), Attachment beyond infancy. American Psychologist, 44, 709-716.

Ainsworth M.D.S. (1990), Some considerations regarding theory and assessment relevant to attachments beyond infancy. W: M.T. Greenberg, D. Cicchetti, E.M. Cummings (red.), Attachment in the Preschool Years. Theory, Research, and Intervention (s. 463-488). Chicago and London: The University of Chicago Press.

Ainsworth M.D.S. (1991), Attachments and other affectional bonds cross the life cycle. W: C.M. Parkes, J. Stevenson-Hinde, P. Marris (red.), Attachment across the Life Cycle (s. 33-51). London and New York: Routledge.

Ainsworth M.D.S., Blehar M.C., Waters E., Wall S. (1978), Patterns of attachment: Assessed in the Strange Situation and at home. Hilsdale, NJ: Erlbaum.

Bowlby J. (1969/2007), Przywiqzanie. Warszawa: Wydawnictwo Naukowe PWN.

Bowlby J. (1977), The making and breaking of affectional bonds: I. Aetiology ans psychopathology in the light of attachment theory. The British Journal of Psychiatry, 130, 201-210.

Bowlby J. (1988), A secure base. New York: Basic Books.

Bowlby J., Parkes C.M. (1970), Separation and loss within the family. W: E.J. Anthony, C. Koupernik (red.), The Child in His Family: International Yearbook of Child Psychiatry and Allied Professions (s. 197-216), New York: Wiley.

Bretherton I. (1995), Attachment theory and developmental psychopathology. W: D. Cicchetti, S.L. Toth (red.), Rochester Symposium on Developmental Psychopathology, Vol. 6. Emotion, Cognition, and Representation (s. 231-260). Rochester, New York: University Press.

Cassidy J. (2008), The nature of child's tie. W: J. Cassidy, P.R. Shaver (red.), Handbook of Attachment. Theory, Research, and Clinical Application. Second edition (s. 3-22). New York and London: The Guilford Press.

Crowell J.A., Treboux D. (1995), A review of adult attachment measures: implications for theory and Research. Social Development, 4, 294-327.

Czub T. (2005), Wiek niemowlęcy. Jak rozpoznać ryzyko i jak pomagać? W: A.I. Brzezińska (red.), Psychologiczne portrety człowieka. Praktyczna psychologia rozwojowa (s. 67-94). Gdańsk: Gdańskie Wydawnictwo Psychologiczne.

Czubak, K. (2018). Doświadczanie miłości w kontekście teorii więzi przez więźniów i nie-więźniów. Annales Universitatis Mariae Curie-Skłodowska, sectio J-Paedagogia-Psychologia, 31(4), 255-273.

Fraley R.C., Davis K.E. (1997), Attachment formation and transfer in young adults' close friendships and romantic relationships. Personal Relationships, 4, 131-144.

Fraley R.C., Shaver P.R. (1998), Airport separation: A naturalistic study of adult attachment dynamics in separating couples. Journal of Personality and Social Psychology, 75(5), 1198-1212.

Fraley R.C., Shaver P.R. (2000), Adult romantic attachment: Theoretical development, emerging controversies, and unanswered question. Review of General Psychology, 4(2), 132-154.

Furman W. (2001), Working models of friendships. Journal of Social and Personal Relationships, 18(5), 583-602. Harris T. (2002), Attachment-related psychodynamics: Another shake to the kaleidoscope. Attachment and Human Development, 4(2), 201-206.

Hazan C., Campa M., Gur-Yaish N. (2006), What is adult attachment? W: M. Mikulincer, G.S. Goodman (red.), Dynamics of Romantic Love. Attachment, Caregiving, and Sex (s. 47-70). New York/London: The Guilford Press. 
Hazan C., Gur-Yaish N., Campa M. (2004), What does it mean to be attached? W: S.W. Rholes, J.A. Simpson (red.), Adult Attachment. Theory, Research, and Clinical Implications (s. 55-85). New York/London: The Guilford Press.

Hazan C., Shaver P. (1987), Romantic love conceptualized as an attachment process. Journal of Personality and Social Psychology, 52, 511-524.

Hazan C., Shaver P. (1990), Love and work: An attachment-theoretical perspective. Journal of Personality and Social Psychology, 59(2), 270-280.

Hazan C., Shaver P. (1994), Attachment as an organizational framework for research on close relationships. Psychological Inquiry, 5, 1-22.

Hazan C., Zeifman D. (1994), Sex and psychological tether. Advances in Personal Relationships, 5, 151-177.

Heffernan, M.E., Fraley, R.C., Vicary, A.M., Brumbaugh, C.C. (2012). Attachment features and functions in adult romantic relationships. Journal of Social and Personal Relationships, 29(5), 671-693.

Liberska H., Głogowska K., Deja M. (2016). Przywiązanie do rodziców i rówieśników jako predyktor samooceny w adolescencji. Czasopismo Psychologiczne, 22(2), 219-227.

Łoś Z. (2010), Dyskusyjnie o klasyfikacji i pomiarze wzorców przywiązania. Psychologia Rozwojowa, 15(2), $61-75$.

Marvin R.S., Britner P.A. (2008), Normative development. The ontogeny of attachment. W: J. Cassidy, P.R. Shaver (red.), Handbook of attachment. Theory, research, and clinical application. Second edition (s. 269-294). New York/London: The Guilford Press.

Mikulincer M., Gillath O., Shaver P.R. (2002), Activation of the attachment system in adulthood: Threat-related primes increase the accessibility of mental representations of attachment figures. Journal of Personality and Social Psychology, 83(4), 881-895.

Mikulincer M., Goodman G.S. (2006), Dynamics of Romantic Love: Attachment, Caregiving, and Sex. New York/London: Guilford Press.

Mikulincer M., Shaver P.R. (2007), Attachment in Adulthood. Structure, Dynamics, and Change. New York/ London: The Guilford Press.

Parkes C.M. (1972), Bereavement: Studies of Grief in Adult Life. London, UK: Tavistock.

Rosenthal N.L., Kobak R., (2010), Assessing adolescents' attachment hierarchies: Differences across developmental periods and associations with individual adaptation. Journal of Research on Adolescence, 20(3), 678-706.

Scharf M., Mayseless O. (2007), Putting eggs in more than one basket: A new look at developmental processes of attachment in adolescence. New Directions for Child and Adolescent Development, 117, 1-22.

Shaver P., Hazan C., Bradshaw D. (1988), Love as attachment: The integration of three behavioral systems. W: R.J.B. Sternberg, M.L. Barnes (red.), The Psychology of Love (s. 68-99). New Haven, CT: Yale University Press.

Stawicka M. (2008), Autodestruktywność dziecięca w świetle teorii przywiazania. Poznań: Wydawnictwo Naukowe UAM.

Trinke S.J., Bartholomew K. (1997), Hierarchies of attachment relationships in young adults. Journal of Social and Personal Relationships, 14(5), 603-625.

Weiss R.S. (1973), Loneliness: The Experience of Emotional and Social Isolation. Cambridge, MA: MIT Press. Weiss R.S. (1977), Marital Separation. New York: Basic Books.

Weiss R.S. (1991), The attachment bond in childhood and adulthood. W: C.M. Parkes, P. Marris, J. Stevenson-Hinde (red.), Attachment across the Life Cycle (s. 66-76). New York: Routledge.

Zeifman D., Hazan C. (1997). A process model of adult attachment formation. W: S. Duck (red.), Handbook of personal relationships: Theory, research and interventions (s. 179-195). John Wiley \& Sons Inc.

Zeifman D., Hazan C. (2008), Pair bonds as attachments. Reevaluating the evidence. W: J. Cassidy, P.R. Shaver (red.), Handbook of Attachment. Theory, Research, and Clinical Application. Second Edition (s. 436-455). New York/London: The Guilford Press.

Ziółkowska B. (2005), Okres wczesnej dorosłości. Jak rozpoznać potencjał młodych dorosłych. W: A.I. Brzezińska (red.), Portrety psychologiczne człowieka (s. 423-468). Gdańsk: Gdańskie Wydawnictwo Psychologiczne. 